\title{
PENGEMBANGAN PERANGKAT PEMBELAJARAN BERBASIS SELF-REGULATED LEARNING PADA MATERI KESEIMBANGAN LINGKUNGAN DAN PERUBAHANNYA UNTUK MENINGKATKAN HASIL BELAJAR KOGNITIF SISWA
}

\author{
Rindah Permatasari $^{1)}$, Muslimin Ibrahim ${ }^{2)}$, Wahono Widodo ${ }^{3)}$ \\ ${ }^{1)}$ Mahasiswa Program Studi Pendidikan Sains, Program Pascasarjana Universitas Negeri Surabaya \\ ${ }^{2), 3)}$ Dosen Pascasarjana Prodi Pendidikan Sains Universitas Negeri Surabaya \\ E-mail: rindahpermatasari@gmail.com
}

\begin{abstract}
Abstrak: Penelitian ini bertujuan untuk menghasilkan perangkat pembelajaran berbasis Self-Regulated Learning pada materi keseimbangan lingkungan dan perubahannya untuk meningkatkan hasil belajar kognitif siswa. Perangkat pembelajaran yang dikembangkan terdiri dari Silabus, RPP, LKS, Handsout yang terdapat Jurnal belajar siswa, dan Lembar penilaian hasil belajar. Aspek Self-regulated learning yang dilatihkan adalah perencanaan, monitoring dan evaluasi. Kelayakan perangkat pembelajaran dilihat berdasarkan aspek kevalidan, kepraktisan dan keefektifan perangkat pembelajaran. Penelitian ini merupakan penelitian pengembangan model 4D dengan menggunakan One Group Pretest-Posttest Design yang diimplementasikan pada 21 siswa kelas X MIA 1 SMA Senopati Sidoarjo. Hasil penelitian menunjukan perangkat pembelajaran sangat valid dengan interval skor penilaian antara 3,3-4 dan reliabilitas antara 92,9\%-99\%. Keterlaksanaan pembelajaran berkategori sangat baik dengan interval skor penilaian antara 3,5-4 dengan rerata reliabilitas 96\%, rerata tingkat keterbacaan perangkat berdasarkan gunning fox indeks adalah 11 dengan kriteria sedang, persentase keterbacaan perangkat pembelajaran berdasarkan lembar keterbacaan perangkat pembelajaran sebesar $97 \%$ dan siswa memberikan respon positif terhadap perangkat pembelajaran sebesar $96 \%$. Peningkatan hasil belajar kognitif siswa dilihat dari rerata nilai $\mathrm{N}$-gain seluruh siswa yaitu 0,68 dengan kriteria sedang, ketuntasan klasikal sebesar 100\%, serta ketuntasan indikator dengan interval 2,7-3,6. Berdasarkan hasil penelitian tersebut maka dapat disimpulkan bahwa perangkat pembelajaran berbasis Self-Regulated Learning pada materi keseimbangan lingkungan dan perubahannya layak digunakan untuk meningkatkan hasil belajar kognitif siswa.
\end{abstract}

Kata kunci: Perangkat Pembelajaran, Self-Regulated Learning, Hasil Belajar Kognitif Siswa

\begin{abstract}
This research's aim is to produce biology learning devices based on Self-Regulated Learning in subject of environmental balance and change to increase cognitive learning outcome of students. The devices consist of a syllabus, lesson plans, worksheets, handouts contained of student learning journal, and assessment sheets of learning outcomes. Self-regulated learning aspect are trained is the planning, monitoring and evaluation. The feasibility aspects of this study are based on validity, practicality and effectiveness of the learning devices. This research is developed by using 4D model with one group pretestposttest design that were tested in 21 students at Senopati senior high school Sidoarjo. The result showed learning devices is very valid with interval of an assessment scores between 3,3-4 and reliability between $92.9 \%-99 \%$. Accomplished learning is very well categorized with an interval of assessment scores between 3.5-4 with average reliability by $96 \%$, the average of legibility learning by Gunning fox index was 11 with a moderate criteria and the readability percentage of the learning devices based on readability sheets is $97 \%$, and the students responded positively to the learning devices by $96 \%$. Cognitive learning outcome of students can be seen with the average value of the $\mathrm{N}$-gain of all students by 0.68 with a moderate criteria, classical completeness of $100 \%$, and learning indicators completeness between 2,7-3,6. Based on these research, it can be concluded that the biology learning devices based Self-Regulated Learning in subject of environmental balance and change is eligible to be used to increase students cognitive learning outcome.
\end{abstract}

Keywords: Learning Devices, Self-Regulated Learning, Cognitive Learning Outcome of Students

\section{PENDAHULUAN}

Pendidikan merupakan suatu proses pengembangan semua aspek kepribadian manusia yang mencakup pengetahuan, nilai, sikap, dan keterampilan yang bertujuan untuk membentuk pribadi suatu individu yang lebih baik. Nur (1998) menyatakan bahwa salah satu tujuan pendidikan adalah menghasilkan manusia yang mampu mendidik dirinya sendiri, menetapkan tujuan sendiri, dan mampu melakukan penguatan atas dirinya sendiri. Hal ini sesuai dengan Undang-undang No.20 tahun 2003 pada Bab 2 pasal 3 dan Peraturan Menteri Pendidikan Nasional Republik 
Indonesia Nomor 23 tahun 2006 yang menyatakan salah satu tujuan pendidikan adalah mengembangkan potensi peserta didik agar menjadi manusia yang memiliki kekuatan spiritual keagamaan, pengendalian diri, kepribadian akhlak serta keterampilan dan mampu mengembangkan budaya belajar untuk pembelajaran diri (Long life education).

Berdasarkan hasil observasi pada siswa kelas X MIA 1 di SMA Senopati Sidoarjo diketahui bahwa salah satu permasalahan yang ditemui guru dalam proses pembelajaran khususnya biologi adalah siswa belum memiliki kesadaran akan pentingnya kemandirian dalam belajar. Selama proses pembelajaran masih ditemui kecurangan-kecurangan yang dilakukan oleh siswa seperti menyalin hasil pekerjaan teman, baik itu tugas individu di kelas ataupun tugas rumah, serta mencontek pada saat pelaksanaan ulangan. Hal-hal tersebut merupakan indikasi kurangnya kesadaran siswa akan pentingnya proses belajar.

Kemampuana untuk mengatur dan mendidik diri sendiri dalam suatu aktivitas atau kegiatan belajar termasuk dalam Self-Regulated Learning. SelfRegulated Learning merupakan suatu proses pengaturan diri dalam pembelajaran sehingga terbentuk individu yang mandiri. "SRL is a process where individuals create self-oriented feedback loops to monitor their effectiveness in completing a task and adapt accordingly to experience success. SRL is viewed within the context of social interactions, as the process is ideally supported when students are interacting with peers, teachers and coaches ". Dari pernyataan tersebut dapat diketahui bahwa, SRL adalah suatu proses dimana individu membuat orientasi diri berupa umpan balik untuk memantau efektivitas mereka dalam menyelesaikan tugas dan beradaptasi untuk menggapai kesuksesan. SRL dilihat dalam konteks interaksi sosial, sebagai proses idealnya ketika siswa berinteraksi dengan teman sebaya,guru dan pelatih (Zimmerman, 1989). Strategi Self-Regulated Learning adalah strategi pembelajaran yang membelajarkan siswa tentang bagaimana strategi pembelajaran yang efektif dan bagaimana serta kapan menggunakannya (Bandura, 1991 dalam Slavin, 2009). Brookfield (1984 dalam Yamin, 2013) menambahkan belajar mandiri atau Self-Regulated Learning adalah belajar yang dilakukan oleh peserta didik secara bebas menentukan tujuan belajarnya, arah belajarnya, merencanakan proses belajarnya, strategi belajarnya, menggunakan sumber-sumber belajar yang dipilihnya, membuat keputusan akademik, dan melakukan kegiatan-kegiatan untuk tercapainya tujuan belajar. Berdasarkan penjelasan-penjelasan mengenai Self-Regulated Learning di atas menunjukan pentingnya strategi pembelajaran yang dapat melatihkan Self-Regulated
Learning pada siswa. Siswa yang memiliki kemandirian dalam belajar akan cenderung mampu untuk merancang, memantau, merefleksikan proses belajar sehingga akan terbentuk pribadi yang lebih percaya diri, mandiri dan dapat meningkatkan hasil belajar.

Salah satu upaya yang dapat dilakukan untuk membentuk individu-individu yang mandiri dan dapat mengatur dirinya dalam belajar adalah dengan membuat perangkat pembelajaran yang dapat melatihkan kemandirian dalam belajar. Strategi yang diduga dapat melatihkan kemandirian dalam belajar adalah strategi Self-Regulated Learning. Strategi Self- Regulated Learning merupakan strategi pembelajaran yang mengajarkan siswa untuk mengatur dirinya dalam belajar mulai dari merencanakan, melaksanakan, memonitor kemajuan belajar hingga mengevaluasi belajar. Self-Regulated Learning dapat melatihkan siswa bagaimana belajar yang efektif dimana hasil evaluasi belajar akan digunakan siswa sebagai bahan pertimbangan dalam merencanakan belajar selanjutnya.

Siswa yang terampil dalam pengaturan diri dalam belajar akan mampu untuk merencanakan dan memperkiraan waktu yang diperlukan untuk menyelesaikan tugas, mengorganisasi materi, dan merefleksikan proses belajar secara sadar sehingga siswa dapat meningkatkan hasil belajar dan membentuk siswa menjadi siswa yang percaya diri dan mandiri. Hal ini sesuai dengan hasil penelitian Asmaul (2014) menyatakan bahwa perangkat pembelajaran berbasis pengaturan diri (self-regulated learning) efektif untuk meningkatkan kemampuan kognitif siswa. Sejalan dengan penelitian sebelumnya, Latifah (2010) menyatakan strategi SRL berpengaruh terhadap prestasi belajar siswa. Sejalan dengan hal tersebut, Afianti (2010) mengemukankan bahwa terdapat hubungan positif dan signifikan antara SRL dengan kesadaran belajar siswa (melatih siswa menjadi pelajar mandiri).

Biologi merupakan salah satu bagian dari sains yang mengkaji pengetahuan tentang makhluk hidup. Objek pembelajaran biologi selain berhubungan dengan alam nyata juga berkaitan dengan proses-proses kehidupan. Pemahaman konsep biologi dapat dilakukan melalui pemberian pengalaman langsung secara ilmiah. Salah satu nilai penting pembelajaran biologi adalah untuk menumbuhkan dan mengembangkan sikap, keterampilan berfikir serta meningkatkan keterampilan dalam menjalankan penyelidikan atau penelitian ilmiah.

Materi keseimbangan lingkungan dan perubahannya merupakan materi biologi SMA kelas X semester 2 yang tercantum dalam Kompetensi Dasar 3.10 menganalisis data perubahan lingkungan dan dampak dari perubahan perubahan tersebut bagi kehidupan. 
Materi ini berisi tentang konsep, prinsip, dan teori yang membicarakan tentang keseimbanan lingkungan, perubahaan lingkungan, pencemaran lingkungan dan upaya penangulangannya, daur ulangan, dan etika lingkungan. Materi keseimbangan lingkungan dan perubahannya ini merupakan materi yang dekat dengan keseharian siswa sehingga diharapkan dengan pemilihan materi ini memudahkan siswa dalam melatihkan keterampilan metakognitifnya.

Berdasarkan hasil analisis terhadap beberapa buku dan lembar kerja siswa (LKS) biologi baik buku sekolah elektronik (BSE) maupun buku-buku biologi yang beredar, diketahui bahwa buku dan lembar kerja siswa (LKS) yang digunakan dalam pembelajaran khususnya biologi belum mengajarkan keterampilan metakognitif. Beberapa buku sudah menambahkan fitur refleksi, namun untuk perencanaan dan monitoring sendiri belum ditemukan. Padahal kedua komponen tersebut merupakan komponen yang penting dalam pembentukan pebelajar yang mandiri. Siswa yang terampil merencanakan, memonitoring dan mengevaluasi setiap kegiatan belajarnya akan menghasilkan siswa yang lebih mandiri dan percaya diri dalam belajar.

Berdasarkan uraian di atas, dengan melihat pentingnya melatihkan siswa untuk mampu mengatur dirinya dalam belajar dan belajar secara mandiri perlu kiranya dikembangkan perangkat pembelajaran biologi berbasis Self-Regulated Learning pada materi keseimbangan lingkungan dan perubahannya untuk meningkatkan hasil belajar kognitif siswa.

\section{METODE PENELITIAN}

Penelitian ini merupakan penelitian yang mengadaptasi model pengembangan 4D. Subjek penelitian pada tahap pengembangan adalah perangkat pembelajaran berbasis self-regulated learning, sedangkan pada tahap implementasi yang menjadi subjek penelitian adalah siswa kelas X MIA 1 SMA Senopati Sidoarjo semester 2 tahun ajaran 2014/2015 dengan sampel penelitian berjumlah 21 siswa.

Penelitian ini meliputi dua tahap yaitu: 1) tahap pengembangan perangkat pembelajaran berbasis selfregulated learning dan 2) tahap implementasi perangkat pembelajaran yang dikembangkan. Pengembangan perangkat pembelajaran mengadaptasi model pengembangan, namun karna keterbatasan waktu tahap penyebaran (disseminate) tidak dilaksanakan. Menurut Thiagarajan dan Semmel (1974), model pengembangan 4D meliputi: tahap pendefinisian (define), tahap perancangan (design), tahap pengembangan (develop), dan tahap penyebaran (disseminate).

Perangkat pembelajaran yang dikembangkan meliputi Silabus, RPP, LKS, Handsout dengan jurnal belajar siswa dan Lembar penilaian hasil belajar. Perangkat pembelajaran atau draft pertama yang telah dikembangkan ini kemudian divalidasi oleh 3 orang pakar. Tahap pengembangan dilanjutkan dengan merevisi perangkat pembelajaran sesuai dengan masukan para pakar. Draft pertama hasil revisi ini menghasilkan draft kedua yang telah direvisi dan dilanjutkan dengan ujicoba terbatas pada 10 orang siswa untuk mengetahui validitas, reliabilitas, sensitivitas, kepraktisan dan keefektifan perangkat pembelajaran.

Tahap selanjutnya yaitu tahap implementasi perangkat pembelajaran pada kelas X MIA 1 . Rancangan penelitian yang digunakan adalah One Group Pretest-Posttest Design yang digambarkan sebagai berikut:

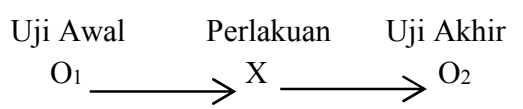

Keterangan:

$\mathrm{O}_{1}$ : Uji awal, bertujuan untuk mengetahui tingkat penguasaan siswa terhadap materi pembelajaran dan keterampilan metakognitif siswa sebelum diberikan perlakuan.

$\mathrm{O}_{2}$ : Uji akhir, bertujuan untuk mengetahui tingkat penguasaan siswa terhadap materi pembelajaran dan keterampilan metakognitif siswa setelah diberikan perlakuan.

$$
\begin{gathered}
\mathrm{X} \text { : Perlakuan pembelajaran dengan } \\
\text { menerapkan Self-Regulated Learning }
\end{gathered}
$$

Kegiatan yang dilakukan pada tahap implementasi ini secara berurutan dimulai dari tes awal, kegiatan belajar mengajar sebanyak tiga kali pertemuan, kemudian dilanjutkan dengan tes akhir. Tujuan dari pelaksanaan tahap implementasi ini adalah untuk memperoleh data yang akan dianalisis secara deskriptif guna menjawab pertanyaan penelitian dan untuk mengembangakn perangkat pembelajaran yang telah final.

Variabel penelitian yang diamati dalam penelitian ini adalah validitas perangkat pembelajaran atau kebenaran isi perangkat pembelajaran, keterbacaan perangkat pembelajaran, keterlaksanaan pembelajaran, peningkatan hasil belajar siswa, serta respon siswa.

Menurut Sugiyono (2011) terdapat dua hal utama yang mempengaruhi kualitas data hasil penelitian, yaitu kualitas instrument penelitian yang berkenaan dengan validitas dan reabilitas instrument dan kualitas atau teknik pengumpulan data yang berkenaan dengan ketepatan cara-cara yang digunakan untuk mengumpulkan data. Adapun teknik pengumpulan data yang digunakan dalam penelitian ini, yaitu: Teknik observasi atau pengamatan untuk mengetahhi keterlaksanaan pembelajaran, angket untuk mengetahui 
keterbacaan perangkat pembelajaran dan respon siswa, serta tes untuk mengetahui peningkatan hasil belajar siswa. Instrument-instrumen yang digunakan dalam penelitian ini meliputi lembar validasi perangkat pembelajaran, lembar keterbacaan perangkat, lembar keterlaksanaan, jurnal belajar siswa, lembar penilaian hasil belajar, dan lembar angket respon siswa.

Validasi komponen perangkat pembelajaran dianalisis menggunakan analisis deskriptif kualitatif yaitu dengan merata -rata skor yang diperoleh dari dua validator. Perangkat pembelajaran dikatakan valid dan dapat digunakan jika hasil analisis validasi perangkat $\geq 2,6$ (diadaptasi dari Ratuman dan Laurens, 2006). Keterbacaan perangkat pembelajaran dapat dihitung dengan menggunakan rumus Gunning fox indeks, sebagai berikut:

Keterbacaan $\mathrm{PP}=0,4\left(\frac{\text { Kata }}{\text { Kalimat }}\right)+100\left(\frac{\text { Kata Sukar }}{\text { Kata }}\right)$

Tingkat keterbacaan perangkat pada kriteris sedang jika tingkat keterbacaan perangkat pada interval 7-11. Keterbacaan perangkat pembelajaran juga dianalisis secara deskriptif kuantitatif dengan meminta siswa untuk memberikan koreksi mengenai keterbacaan LKS dan Handsout pada lembar instrument. Perangkat dikategorikan menarik dan dapat dipahami jika persentase yang diberikan oleh siswa lebih dari $60 \%$. Keterlaksanaan RPP dianalisis dengan menghitung presentase dan rata-rata skor yang diberikan oleh pengamat terhadap keterlaksanaan pembelajaran. ketuntasan hasil belajar siswa dilihat dari peningkatan hasil belajar yang dianalisis dengan ujinormalitas gain, ketuntasan indikator, ketuntasan individual dan ketuntasan klasikal. Siswa dapat dikatakan mengalami peningkatan hasil belajar apabila nilai $N$-Gain yang diperoleh antara 0,3-0,7 sedangkan siswa dikatakan tuntas secara individu apabila siswa memperoleh skor 2,67, Skor ini berdasarkan nilai KKM yang ditetapkan Permendikbud RI No 104 Tahun 2014.

\section{HASIL PENELITIAN DAN DISKUSI}

Tujuan dari penelitian ini adalah untuk mengembangkan perangkat pembelajaran berbasis SelfRegulated Learning yang layak digunakan dalam pembelajaran Biologi SMA Kelas X pada materi keseimbangan lingkungan dan perubahannya untuk meningkatkan hasil belajar kognitif siswa. Penelitian dilakukan dalam dua tahap yaitu tahap pengembangan perangkat dan tahap implementasi yang dilakukan pada 21 orang siswa kelas X MIA 1 di SMA Senopati Sidoarjo dengan 3 kali pertemuan.

Perangkat pembelajaran yang dikembangkan meliputi RPP, LKS, Handsout yang dilengkapi jurnal belajar siswa, dan Lembar penilaian hasil belajar.

Rencana pelaksanaan pembelajaran (RPP)

Pengembangan Perangkat Pembelajaran Berbasis Self-

Regulated Learning pada.... dikembangkan untuk tiga kali pertemuan. Pada pertemuan pertama, RPP menggunakan model pembelajaran Kooperatif tipe STAD untuk menjelaskan materi keseimbangan lingkungan dan perubahannya. Pada pertemuan kedua, RPP menerapkan model pembelajaran langsung untuk menjelaskan materi pencemaran lingkungan. Sedangkan pertemuan ketiga, model pembelajaran yang diterapkan Kooperatif tipe STAD untuk menjelaskan materi daur ulang limbah dan etika lingkungan. RPP yang dikembangkan dirancang untuk melatihkan keterampilan metakognitif siswa, hal ini terlihat pada bagian pendahuluan, isi dan penutup yang disisipkan kegiatan perencanaan, monitoring dan evaluasi pembelajaran yang dibimbing oleh guru.

Lembar kegiatan siswa (LKS) yang dikembangkan berbasis Self-Regulated Learning untuk tiga pertemuan dengan menyisipkan fitur kegiatan perencanaan, monitoring, dan evaluasi pada tiap LKS. LKS pertama merupakan kegiatan melatih strategi belajar siswa, hal ini bertujuan agar siswa dapat lebih menguasai teknik belajar efektif. LKS kedua dirancang untuk menganalisis pencemaran air dengan melihat pengaruh $\mathrm{CH}_{3} \mathrm{COOH}$ dalam air dengan konsentrasi berbeda pada pertumbuhan perkecambahan tumbuhan. LKS ketiga dirancang untuk mengatasi masalah lingkungan dengan merancang produk daur ulang limbah.

Handsout siswa digunakan sebagai penunjang materi keseimbangan lingkungan dan perubahannya. Selain itu. Handsout yang dikembangkan memiliki beberapa fitur yaitu Deskripsi Handsout, KD dan indikator, Peta konsep, Self- regulated learning, Jurnal Belajar Siswa yang meliputi lembar perencanaan, monitoring, lembar catatan hasil belajar dan evaluasi, Bioinfo, dan Materi. Handsout terdiri dari tiga submateri yaitu keseimbangan lingkungan dan perubahan lingkungan, pencemaran lingkungan, serta daur ulang limbah dan etika lingkungan.

Perangkat pembelajaran yang baik merupakan perangkat pembelajaran yang valid, praktis dan efektif (Nieveen, 1999). Valid artinya benar menurut bukti, praktis artinya perangkat yang dikembangkan dapat dengan mudah digunakan oleh guru dan siswa dalam pembelajaran, efektif artinya pembelajaran yang dilakukan dengan menggunakan perangkat pembelajaran yang dikembangkan mampu mencapai tujuan yang ditetapkan (Ibrahim, 2003).

Perangkat pembelajaran yang divalidasi terdiri dari RPP, LKS, Handsout, dan Lembar Penilaian Hasil Belajar. Berdasarkan hasil penilaian para pakar, Perangkat pembelajaran berbasis Self- regulated learning yang dikembangkan meliputi RPP, LKS, Handout, dan Lembar penilaian hasil belajar dinyatakan valid dengan kategori sangat valid dengan interval skor 
penilaian antara 3,3 sampai 4 dengan reliabilitas antara $92,9 \%$ hingga $99 \%$. Hal ini menyatakan bahwa perangkat pembelajaran yang dikembangkan telah memenuhi standar valid dan reliable sebagai panduan guru dalam mengajarkan materi keseimbangan lingkungan dan perubahannya serta untuk meningkatkan hasil belajar kognitif siswa. Suwardi (2007) menyatakan bahwa, Perencanaan merupakan langkah penting untuk mencapai keberhasilan pembelajaran. Apabila rencana pembelajaran disusun secara baik maka tujuan pembelajaran dapat dicapai secara efektif dan efisien. Perangkat pembelajaran yang dikembangkanpun telah disesuaikan dengan permendikbud RI No 81 A mengenai format penyusunan RPP dan perangkat pembelajaran lainnya yang mencakup: Identitas sekolah, mata pelajaran, dan kelas/semester, materi pokok, alokasi waktu, KI, KD dan indikator pencapaian kompetensi, tujuan pembelajaran, materi pembelajaran, pendekatan, model, dan metode pembelajaran, media, alat dan sumber belajar, langkah- langkah kegiatan pembelajaran dan penilaian sehingga pada saat dilakukan validasi perangkat pembelajaran, aspek ini mendapatkan skor tertinggi dengan kriteria sangat valid.

Keterlaksanaan Rencana Pelaksanaan Pembelajaran digunakan oleh pengamat untuk mengetahui dan menilai keterlaksanaan langkah- langkah pembelajaran biologi berbasis self-regulated learning yang disesuaikan dengan RPP. Keterlaksanaan perangkat RPP berbasis Self-Regulated Learning diamati dengan menggunakan lembar keterlaksanaan perangkat RPP yang diamati oleh dua orang pengamat berdasarkan aspek kegiatan belajar mengajar yang terdiri atas kegiatan pendahuluan, inti, dan penutup, serta pengelolaan waktu, dan suasana kelas.

Berdasarkan hasil analisis data, diketahui bahwa RPP terlaksana $100 \%$. Skor interval rata-rata tiap aspek pembelajaran antara 3,5-4 dengan kategori sangat baik. Keterlaksanaan RPP dinyatakan dapat dipercaya atau reliable berdasarkan hasil perhitungan reliabilitas sebesar $96 \%$. Hal ini menyatakan bahwa RPP yang dikembangkan sangat baik dan dapat digunakan sebagai acuan atau pedoman guru dalam menyampaikan materi keseimbangan lingkungan dan perubahannya.

Analisis kemampuan kognitif siswa ditentukan berdasarkan peningkatan hasil belajar siswa setelah dilakukan proses pembelajaran. Hasil belajar merupakan skor ketercapaian indikator pembelajaran yang diperoleh siswa dari tes hasil belajar. Penilaian hasil belajar siswa diukur dengan menggunakan lembar penilaian hasil belajar pretest dan posttest yang diberikan sebelum dan setelah pembelajaran dengan menerapkan strategi Self-Regilated Learning. Lembar penilaian hasil belajar dikembangkan berdasarkan kompetensi dasar 3.10 yang diuraikan menjadi 9 indikator dan 21 tujuan pembelajaran. Berdasarkan indikator dan tujuan pembelajaran tersebut dirumuskan 30 butir soal pilihan ganda dengan 5 pilihan jawaban.

Analisis ketuntasan hasil belajar siswa dilihat berdasarkan peningkatan hasil belajar yang diperoleh siswa dari tes hasil belajar pretest dan posttest yang ditunjukkan pada Grafik 1. Berdasarkan Grafik 1 diperoleh informasi bahwa seluruh siswa tidak tuntas pada saat dilakukan pretest dengan rentang nilai 1,202,40 namun setelah dilakukan pembelajaran berbasis Self-regulated learning diketahui bahwa terjadi peningkatan hasil belajar dimana seluruh siswa tuntas dengan rentang nilai 2,8-3,86. Analisis $\mathrm{N}$-gain terhadap masing-masing siswa juga menunjukan adanya peningkatan hasil belajar. Berdasarkan hasil analisis $\mathrm{N}$-gain, diketahui bahwa rerata skor $\mathrm{N}$-gain yaitu 0,68 dengan kriteria sedang, dengan interval $N$ - gain siswa antara 0.57 sampai 0.92 dengan kategori sedang hingga tinggi.

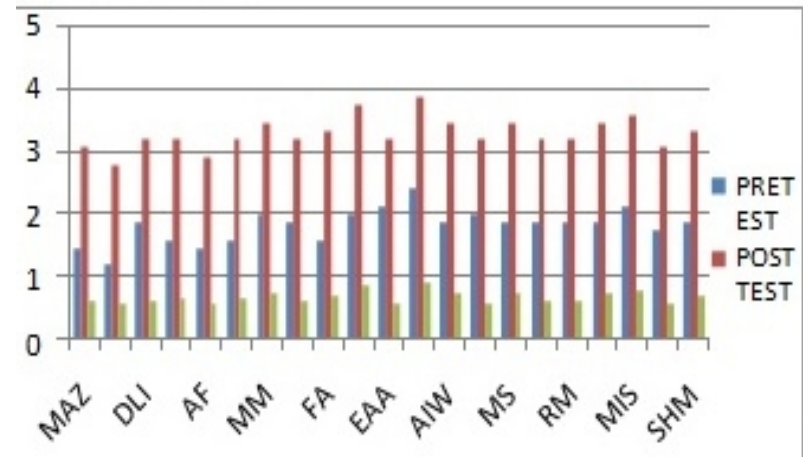

Gambar 1. Analisis N-gain

Peningkatan hasil belajar siswa menandakan adanya peningkatan pengetahuan siswa yang berkenaan dengan materi yang telah diajarkan dengan pembelajaran berbasis Self-regulated learning. Hasil tersebut didukung oleh Asmaul (2014) yang menyatakan bahwa perangkat pembelajaran berbasis Self-regulated learning mampu meningkatkan hasil belajar siswa. Sejalan dengan pendapat tersebut, Ocak (2013) menyatakan bahwa terdapat hubungan positif antara Self-regulated learning dalam meningkatkan hasil belajar matematika siswa. Jenkins (2009) menambahkan bahwa siswa yang menerapkan pembelajaran mandiri (Self-regulated learning) secara statistik meningkatkan hasil belajar matematika siswa dan pertumbuhan akademik secara signifikan. Perbedaan peningkatan hasil belajar siswa dikarenakan perbedaan kemampuan kognitif siswa. Seperti Piaget yang mengasumsikan bahwa peserta didik tumbuh melalui urutan perkembangan intelektual yang sama, tetapi pertumbuhan itu berlangsung dengan kecepatan yang berbeda (Jufri, 2013).

Berdasarkan analisis ketuntasan indikator pembelajaran pada Grafik 2 diketahui bahwa seluruh indikator pembelajaran tidak tuntas pada saat dilakukan 
pretest dengan rentang nilai 1,3-2,5 dan setelah dilakukan pembelajaran diketahui bahwa terjadi peningkatan nilai capaian ketuntasan indikator pembelajaran dimana seluruh indikator tuntas dengan rentang nilai 2,7-3.6. Hal ini menggambarkan bahwa siswa telah tuntas dan menguasai semua indikator pembelajaran yang harus dicapai dalam kompetensi pembelajaran. Berdasarkan analisis sensitivitas butir soal hasil belajar, diketahui seluruh item soal pada lembar penilaian hasil belajar dinyatakan sensitif dengan interval skor antara 0,30 sampai 0,60 .

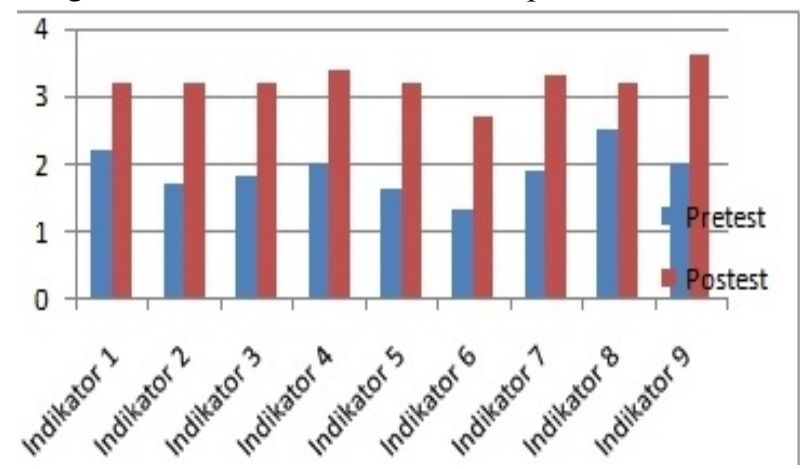

Gambar 2. Sensitifitas Soal pretest \& postest

Ketercapaian ketuntasan indikator pembelajaran maka siswa dinyatakan telah mencapai kompetensi yang harus dicapai pada materi tersebut. Sehingga dapat disimpulkan bahwa setelah proses pembelajaran berbasis Self-regulated learning, siswa dapat menuntaskan indikator pembelajaran atau mencapai kompetensi dasar yang harus dicapai pada materi tersebut. Hal ini sesuai dengan Permendikbud 104 tentang penilaian hasil belajar yang menyatakan bahwa Penilaian Hasil Belajar oleh Pendidik menggunakan acuan kriteria, yang merupakan penilaian kemajuan peserta didik dibandingkan dengan kriteria capaian kompetensi yang ditetapkan dengan skor rerata untuk ketuntasan kompetensi pengetahuan paling kecil 2,7. Analisis sensitivitas butir soal pengetahuan menunjukan bahwa seluruh soal dinyatakan sensitif sehingga dapat mengukur efek-efek pembelajaran. Secara keseluruhan, skor interval sensitivitas butir soal antara 0.3 sampai 0.6. suatu butir soal dinyatakan sensitif bila harga sensitifitasnya lebih dari atau sama dengan 0,3 (Arikunto, 2012). Menurut Grounland (1985) indeks sensitivitas yang efektif terdapat diantara 0 sampai 1 , dan nilai positif yang lebih besar menyatakan butir soal yang lebih besar kepekaannnya terhadap efekefek pembelajaran. Butir soal yang mempunyai sensitivitas $\geq 0,30$ dapat disebut peka terhadap pembelajaran (Aiken, 1997).

Berdasarkan hasil penelitian yang telah dilakukan, ditemukan hal-hal sebagai berikut:

1. Perangkat Perangkat pembelajaran berbasis Selfregulated learning yang dikembangkan meliputi RPP, LKS, Handout, Lembar penilaian hasil belajar dan Angket keterampilan metakognitif. Berdasarkan hasil validasi, perangkat dikatakan valid dengan kategori sangat valid dengan interval skor penilaian antara 3,3 sampai 4 dengan reliabilitas antara $92,9 \%$ hingga $99 \%$.

2. Tingkat keterbacaan perangkat pembelajaran berdasarkan perhitungan Gunning Fox Indeks terletak pada tingkat 11 dengan kriteria sedang. Sedangkan persentase keterbacaan perangkat pembelajaran berdasarkan lembar keterbacaan perangkat pembelajaran sebesar $97 \%$ yang mengindikasikan perangkat pembelajaran menarik dan mudah dipahami oleh siswa.

3. Perangkat Perangkat pembelajaran berbasis Self-regulated learning merupakan perangkat yang praktis untuk digunakan. Hal ini terlihat dari hasil analisis keterlaksanaan pembelajaran bahwa seluruh kegiatan pembelajaran pada rencana pelaksanaan pembelajaran terlaksana $100 \%$ dengan interval skor 3,5-4,0 dengan kategori sangat baik pada setiap aspek pembelajaran dengan rerata reliabilitas 96,13\%.

4. Perangkat Perangkat pembelajaran berbasis Self-regulated learning meningkatkan hasil belajar kognitif dan keterampilan metakognitif siswa. Peningkatan hasil belajar kognitif siswa dapat dilihat dari ketuntasan seluruh indikator pembelajaran dengan rentang skor 2,7 sampai 3,6 dan rerata nilai $N$-gain seluruh siswa yaitu 0,68 dengan kriteria sedang, ketuntasan klasikal sebesar $100 \%$.

5. Perangkat Perangkat pembelajaran berbasis Self-regulated learning mendapatkan respon positif dari siswa yang terlihat dari hasil analisis angket respon siswa yaitu $96 \%$.

\section{KESIMPULAN}

\section{A. Simpulan}

Berdasarkan hasil penelitian, analisis data, dan pembahasan, didapatkan beberapa temuan yang dapat disimpulkan bahwa Perangkat pembelajaran berbasis Self-regulated learning layak digunakan dalam pembelajaran pada materi keseimbangan lingkungan dan perubahannya serta untuk meningkatkan hasil belajar kognitif siswa.

\section{B. Saran}

Berdasarkan hasil analisa data penelitian dan kegiatan penelitian yang telah dilakukan, maka dapat disarankan hal sebagai berikut:

1. Perangkat pembelajaran Biologi SMA kelas $\mathrm{X}$ berbasis self-regulated learning dapat menjadi salah satu alternatif acuan bagi guru dan peneliti lain dalam mengembangkan perangkat pembelajaran sejenis pada materi lain sebagai upaya menghasilkan 
pelajar mandiri.

2. Guru perlu memastikan siswa telah benar-benar memahami seluruh aspek perencanaan, monitoring dan evaluasi sehingga dalam pengisian jurnal belajar dan angket keterampilan metakognitif, siswa tidak mengalami kebingungan.

3. Guru perlu mengontrol jawaban siswa pada angket keterampilan metakognitif dan jurnal belajar siswa untuk menghindari bias dan pengosongan jawaban pada kedua instrument penilaian tersebut.

4. Guru perlu memanajemen waktu sebaik mungkin dalam melatihkan keterampilan metakognitif mengingat banyaknya waktu yang dibutuhkan dalam melatihkan keterampilan tersebut.

\section{REFERENSI}

Afianti, R. Hartati, S. \& Sawitri, D.R. (2010). Hubungan antara Self-Regulated Learning( SRL) dengan kemandirian pada siswa. Jurnal Pendidikan Undip, 1-19.

Arikunto \& Suharsimi. 2012. Dasar-dasar Evaluasi Pendidikan. Jakarta: PT. Bumi Aksara.

Badan Standar Nasional Pendidikan, (2007). Permendiknas RI No.41 Tahun 2007 Tentang Standar Proses untuk Satuan Pendidikan Dasar dan Menengah. Jakarta: BSNP.

Gronlund. N. E. (1982). Measurement and evaluation teaching. Canada: Collier Macmillan Canada, Ltd

Hake. (1999). Analyzing change/gain scores. (Online). http://www.physicsindiana.edu/sdi/AnalyzingChange-Gain. pdf.

Ibrahim. M. (2003). Pengembangan Perangkat Pembelajaran. Jakarta: Direktorat Jendral Peningkatan Mutu Pendidikan dan Tenaga Kependidikan, Departemen Pendidikan Nasioanal.

Jenkins, J., Sings. (2009). "The Effects of Explicit SelfRegulated Learning Strategy Instruction on Mathematics Achievement". ProQuest LLC, Ph.D. Dissertation, The University of North Carolina at Charlotte.

Jufri, W. (2013). Belajar dan pembelejaran sains. Bandung: Pustaka Reka Cipta.
Latifah, E. (2010). Kajian Meta Analisis: Strategi SelfRegulated Learning dan Prestasi Belajar. Jurnal Psikologi. Vol 37. No.1, 110-128.

Lutfauziah, A. (2014). Pengembangan Perangkat Pembelajaran Berbasis Pengaturan Diri (SelfRegulated Learning) Pada Biologi SMA Untuk Melatih Keterampilan Memecahkan Masalah.

Nur, M. (1998). Teori Pembelajaran Sosial. Surabaya: PSMS.

Ocak, G. \& Ahmet, Y. (2013). "Examination of the Relationships between Fifth Graders' SelfRegulated Learning Strategies, Motivational Beliefs, Attitudes, and Achievement". Educational Sciences: Theory \& Practice 13(1) • Winter • 380-387.

Peraturan Menteri Pendidikan Nasional Republik Indonesia Nomor 23. (2006). Standar Proses untuk Satuan Pendidikan Dasar dan Menengah. Jakarta: Menteri Pendidikan Nasional.

Peraturan Menteri Pendidikan Nasional Republik Indonesia Nomor 104. (2014). Penilaian Hasil Belajar. Jakarta: Menteri Pendidikan Nasional.

Slavin, R.E. (2009). Cooperative Learning Teori, Riset dan Pratik. Bandung: Nusa media.

Sugiyono. (2011). Metode Penelitian Kuantitatif Kualitatif dan $R \& D$. Bandung: CV Alfabeta.

Suwardi. (2007). Manajemen Pembelajaran. Salatiga: Stain Salatiga Press.

Thiagarajan, S., Semmel, D., \& Semmel, D. M. (1974). Instructional Development for Training Teachers of Exceptional Children: A Sourcebook. Indiana: Indiana University.

Undang-undang Republik Indonesia No.20. (2003). Sistem Pendidikan Nasional. Jakarta: Presiden Republik Indonesia.

Yamin, martinis. (2013). Strategi dan metode dalam model pembelajaran. Jakarta: Referansi.

Zimmerman, B.J. (1998). Academic Studying and development of Personal Skill: A SelfRegulatory Perspective. Journal of Education Psycologist 33 (2/3), 73-86. 